\title{
122. Kindliche Zwerchfelldefekte. Behandlung und Spätergebnisse
}

\author{
P. Rumpf, L. Zumfelde, E. Müller und D. Günther \\ Chirurgische Klinik A der Universität Düsseldorf (Prof. Dr. K. Kremer)
}

\section{Diaphragmatic Defects in Children: Treatment and Follow-up}

Summary. From 1956-1972, 45 children received surgical treatment for congenital defects of the diaphragm. Surgery is essential in neonates, but optional in older children. The approach was thoracic in 29 cases and abdominal in 16 . Other anomalies were found in about 50 percent of cases, so that there was a high mortality rate of 17.8 percent. Clinical, spirometric, and radiographic follow-up examinations were carried out in 26 patients 4-20 years after the operation. All felt well; slight or moderate respiratory difficulties, thoracic deformities or scoliosis were noted in some patients, and these were commoner in patients in whom a thoracic approach had been used. Pleural scars, restricted diaphragmatic motility, and respiratory insufficiency were equally common in both groups.

Key words: Diaphragm, defects, congenital - Approach, surgical, abdominal/thoracic - Comparison, retrospective.

Zusammenfassung. Operation von 45 kindlichen kongenitalen Zwerchfelldefekten von 1956-1972. Operation bei Neugeborenen dringend, bei älteren Kindern elektiv. 29 mal thorakales, $16 \mathrm{mal}$ abdominales Vorgehen. Etwa 50\% Zusatzanomalien, deswegen hohe Operationsmortalität von 17,8\%. Klinische, spirometrische und röntgenologische Nachuntersuchungen von 26 Patienten 4-20 Jahre nach der Operation. Ergebnisse: Alle subjektives Wohlbefinden, leichte bis mäßige respiratorische Ventilationsstörungen, Thoraxdeformitäten oder Skoliosen, bei der thorakal operierten Gruppe häufiger. Pleuraschwarten, Minderung der Zwerchfellbeweglichkeit, Minderbelüftung der Lunge gleich häufig bei beiden Gruppen.

Schliisselwörter: Kindliche Zwerchfelldefekte, thorakaler und abdominaler Zugang, vergleichende Spätergebnisse.

\section{Der Fall eines monströsen Brustwandtumors bei generalisierten chondrodysplastischen Skeletabarten}

\author{
J. Konradt, R. Häring und B. Hagen \\ Chirurgische Klinik und Poliklinik im Klinikum Steglitz der Freien Universität Berlin
}

\section{Monstrous Tumor of the Chest Wall with Generalized Chondrodysplastic Skeletal Aberrations}

Summary. The authors describe the case of a 48 -year-old man who had suffered from multiple chondrodysplastic skeletal aberrations and giant osteochondroma of the right lateral thoracic and abdominal wall since birth. The tumor had its origin between the 10th and 11th ribs and infiltrated the muscles of the diaphragm and abdominal wall. After removal, a lyophilized dura graft was necessary. The clinical picture is discussed with reference to the Ellis van Creveld syndrome.

Key words: Exostosis, of cartilage, generalized - Tumor, chest wall - Syndrome, Ellis van Crefeld. 